\title{
A CONTRIBUTION TO THE LIFE HISTORY OF SILPHIUM.
}

CONTRIBUTION FROM THE HULL BOTANICAL LABORATORY. XVII.

WILLIAM DAYTON MERRELL.

$$
\text { (WITH PLATES III-X) }
$$

INTRODUCTION.

THE flowers of Compositae are favorable for morphological study, in that several closely connected stages may be obtained in a single section. The broad outlines of the organogeny of the flower were early discovered, and it has only remained for later investigators to examine the more minute details.

Aside from an interest in the family as being the highest among dicotyledons, the division of labor among the flowers of a head deserves attention. This is carried so far in Silphium that the ray-flowers are ovulate and without stamens; while the disk-flowers are staminate and without ovules, the style never forking. It might be expected that some transitional stages in the abortion of stamens or of ovules could be found, and the present study was undertaken with that in view. The results obtained in this particular were very meager, but the investigation led to the discovery of several unexpected phenomena, which are herewith presented.

\section{MATERIAL AND METHODS.}

The material was collected during the summers of 1896 , I 897, and I 899, in the vicinity of Chicago. Unfortunately, most of the collections had to be made in the latter part of the day, and this probably accounts for the small number of cells found in process of division. Even in the youngest buds it was found to be advantageous to pick off the outer involucral scales, partly $1900]$ 
because they interfered with the rapid penetration of the fixing fluid, but more especially because their brittleness very quickly spoiled the edge of the microtome knife. The older akenes, containing embryo-sacs or embryos, were picked off separately, and cut one at a time.

For fixing the early stages of development, as well as the mature embryo-sac structures, the best results were obtained with a I per cent. solution each of chromic acid and acetic acid. A weaker solution, containing 0.7 per cent. chromic acid and 0.3 per cent. acetic acid, worked well, especially when the specimens were first dipped for a moment in alcohol. Flemming's weaker solution was tried for killing embryo-sac stages, but was abandoned as being unnecessary. A saturated solution of picric acid in 70 per cent. alcohol, with a small addition of acetic acid, was frequently used, and was found to be by far the best for all stages of embryos, as it penetrated the hard ovary wall more quickly. After dehydration the objects were brought through xylol into paraffin, and cut in serial sections.

Delafield's haematoxylin, either alone or followed by erythrosin, was found to be the best stain for floral development stages and for embryos. For embryo-sacs, safranin-gentianviolet, cyanin-erythrosin, and Heidenhain's iron-alum-haematoxylin were used; also a combination of fuchsin and iodin-green. For the nuclei within the pollen grains, safranin-gentianviolet, and especially the iron-alum-haematoxylin, gave good resuits.

The following five species of Silphium, growing near Chicago, were examined, a more or less complete series in each being made: S. integrifolium Michx., S. trifoliatum L., S. terebinthinaceum L., S. Taciniatum L., and $S$. perfoliatum L. Most of the statements apply to all these species, hence no attempt will be made to separate them in the account, excepting in cases where points of specific difference are under discussion.

My acknowledgments are due to Professor John M. Coulter and to Dr. Charles J. Chamberlain for great assistance rendered during the course of the work. 
ORGANOGENY OF THE FLOWER.

On account of the difference in the development of the disk and ray flowers, it is necessary to consider the two separately. It has been found, also, that a clear understanding of the sequence and relations of the organs in the disk flowers assists greatly in the interpretation of the more irregular development of the ray flower.

Disk flowers.-The earliest appearance of the disk flowers upon the receptacle is shown in fig. $I$, the broader protuberance $(d)$ being the receptacle of the individual flower, and the narrower one $\left(b r_{1}\right)$ the subtending bract. A second bract $\left(b r_{2}\right)$ is just appearing. Just before the appearance of the first floral organs the receptacle is of the form shown in fig. $2, d_{2}$, being somewhat broader than high, and very symmetrical in outline.

The outline of the receptacle soon becomes angular by the upward growth of a marginal ring ( $f g .2, d_{1}$, fig. 3 ), which is the beginning of the corolla tube. In fig. 4 the corolla tube has begun to curl inward over the top of the flower, and an inner set of five hemispherical protuberances $(s t)$, the young stamens, have appeared. The appearance of the carpels $(k$, figs. 5,6$)$ is accompanied by a broadening of the receptacle, which regains its original proportions as the stamens and carpels acquire a more erect position ( figs. 7,8 ).

In figs. 7 and 9 a notch may be seen on each side at the base of the corolla; just above an annular swelling. This ring marks the position of the calyx, which soon appears ( $f g . I 0, p a)$ as a rudimentary pappus of two or three whorls of short hairs, each hair consisting of about three cells $(f g . I I)$. The nectary consists of a ring around the base of the style $(f g .9, n)$.

Martin's account for Aster and Solidago (I9) agrees in a general way with the account of Silphium here given. However, he finds the calyx in those forms arising much earlier, in fact almost simultaneously with the stamens.

It is well known that in many Compositae the base of the style is spirally coiled, and the straightening of this spiral at maturity constitutes the stylar thrust by which the pollen is 
brushed out of the stamen tube. My preparations show no such device in Silphium. A comparison of figs. 9, IO, II shows that while at one time the style is actually longer than the stamens ( $f i g . I O)$, the stamens soon overtake the style again ( $f i g . I I)$. As this is in a flower where the pollen-mother cells have reached a late synapsis stage, and the maturity of the pollen follows rapidly, it would seem hardly probable that the style could become coiled before the dehiscense of the anthers. The stylar thrust seems to be accomplished rather by an actual increase in the length of the style, partially, at least, by mere cell elongation.

It will be seen that there is no trace of an ovule, or even of an ovary, in the disk flower. In other respects the resemblance to Helianthus (Sachs) is quite close.

Ray flowers. - The ray flowers occupy about two turns of a spiral upon the receptacle. As the individuals of the two rows alternate with each other, only one can ever appear in a single radial longitudinal section of a head. Moreover, in serial sections, never more than two rays, one each from the inner and outer rows, are cut near enough to the radial plane to be valuable for study. It will be seen that in the form of the young ray flower Silphium shows a very close resemblance to Aster and Solidago, especially when, as happens in the great majority of cases, rudimentary stamens are present.

The ray flowers of the outer row $(r$, figs. I, 2) are subtended by bracts of the involucre, which are so closely folded over in the bud as to distort the young flower for a considerable period. This compression on the anterior side is plainly visible in $f g$. I2, where the corolla is starting, and is still noticeable in fig. $\mathrm{I}_{3}$, where the stamens $(s t)$ are just appearing. Fig. I4 shows in addition the young carpels $(k)$, and figs. 15,16 show the beginning of the ovule $(o v)$. At about the stage shown in fig. 14 the corolla tube begins to grow more rapidly on the anterior side, and is thus pushed away from the subtending bract. The opening of the tube is gradually made smaller by the growth of its lateral edges, which finally lap past each other and give rise to such appearances of the corolla as are shown in figs. $18-24$, 
dependent upon the age of the bud and the exact portion of these folds appearing in the section. This infolded portion finally unrolls to form the limb of the corolla.

Although the stamens never reach maturity in the ray flowers, they are to be found in the great majority of young flowers. While one may be in doubt as to their identity in fig. $\mathrm{I}_{3}$, conclusive proof of their presence is found in figs. $14,15,16$. Fig. 20 shows a single anterior stamen in median section, whereas figs. I8, I9, of almost the same age, show no such rudiment, even in lateral sections. The significance of this last statement is seen upon an examination of fig. $2 I$, in which only the two carpels $(k)$ appear in a median section, while, in a lateral section $(f i g .21, a)$, two stamen rudiments $(s t)$ are found. In one head, two flowers were found, each showing a single stamen which had developed to the pollen-mother cell stage (fig. 24).

The ovary arises as a cavity below the carpels, soon widening at the base as the ovule becomes visible. The Anlage of the ovule appears slightly toward the posterior side of the base of the ovary (figs. I5, I6), grows obliquely upward (figs. 18,19 ), and soon becomes erect (figs. 20,2I). In the last figure cited, the apex of the nucellus is already pushed slightly to one side, but hardly enough to warrant the statement of Sachs (I4, P. 572) that the nucellus, when first visible, stands laterally below the apex of the funiculus, a mode of development for some anatropous ovules first described by Cramer (ibid.), and later called in question, at least for Compositae, by Köhne (ibid.). It seems plain that in a stage just earlier than that of fig. $2 I$, perhaps in fig. 20, the cell which later becomes recognizable as the archesporium occupies an exactly terminal position upon the young ovule; and the bulging on the anterior side, already begun in fig. $2 I$, is merely the beginning of the integument, which, growing from now on more rapidly than the nucellus, forces the latter to a lateral position, and finally completely inverts it (figs. 22-25).

The often affirmed lateral origin of the ovule is thrown in doubt by the fact that Martin (I9) relates it by its bundle, 
in Aster and Solidago, to the posterior or "upper" carpel. The Anlage of the ovule is said to be excentric, and nearer to the posterior carpel, a position which Warming figures for Senecio, but which is hard to explain if, as all the earlier writers agreed, the ovule belongs to the anterior carpel.

I find that the ovule of Silphium is generally posterior in origin $(f i g .16)$, but it may sometimes arise anteriorly ( $f i g .17$ ). This fact suggests that the excentric origin of the ovule is of but slight significance, since it may vary in the same species. On comparing the course of the bundles with that described for Aster and Solidago, I find that the axial bundle, instead of ending abruptly just below the edge of the funiculus, passes directly into the ovule (figs. 24, 26, 27). Whatever may be the condition in other Compositae, the ovule of Silphium, as shown by its origin and its bundle relations, is the termination of the floral axis, that is, the ovule is cauline. The oblique position of its Anlage is correlated with the position which must sooner or later be taken by the funiculus of an anatropous ovule in an ovary of limited size.

It should be noted, in passing, that the bundle does not terminate in the upper end of the ovule, but continues in the integument to a point on a level with the embryo sac (fig. 27). This is not in agreement with the recent work of Mlle. Goldflus (27) upon Composite ovules, according to which the bundle ends directly above the chalazal region, and is connected to the antipodals by a strand of elongated conducting cells.

Nectaries.- It has been suggested that the nectaries of Compositae are modified stamen rudiments. The disk flower of Silphium offers no conclusive evidence for or against this view, as the nectar disk occupies a position within the stamen whorl, and might be interpreted as consisting of the confluent rudiments of an inner whorl of stamens. The nectary in the ray flower is also a ring, less prominent than in the disk flower, but even more closely related to the base of the style. The general absence of maturing stamens here makes a comparison of the two rather difficult. But in the two cases of older stamens 
which I found, the nectary was in each case below the stamen (fig. 24). It is hardly conceivable that the nectary of the ray flower is formed from an outer stamen whorl, not yet completely lost in the genus, while in the disk flower it comes from an inner set which is absent in all the tetracyclic Sympetalae. It is much more reasonable to regard the nectary as an organ of independent origin.

DEVELOPMENT OF THE MEGASPORE AND EMBRYO SAC.

When the ovule has reached the stage shown in $f g .22$, the hypodermal archesporium is easily recognizable at the end of an axial row of cells ( fig. 28). Its cytoplasm is finely granular, and its nucleus has already left the resting condition, showing a continuous spirem thread along which the chromatin granules are arranged. Fig 29, from an ovule of about the age of the one in fig. 23, shows the nucleus, with a prominent nucleolus and eight bodies of a different staining reaction, the chromosomes. There is as yet no trace of a spindle. In fig. 30 , taken from the ovule outlined in $f i g$. 24, the equatorial plate is fully formed. A complete count of chromosomes was not possible here, owing to their being so closely crowded together. Six were plainly visible, and a comparison with fig. 29, and with the corresponding division of the pollen mother cell ( fig. 54), leads certainly to the conclusion that eight is the characteristic reduction number. I have made no accurate count of the chromosomes in other tissues, but dividing nuclei found in the large tapetal cells appear to have many more than eight, probably sixteen.

Guignard (15) describes the reduction division in the ovule of Allium ursinum as occurring in the archesporial cell, which here produces a row of four cells, the innermost of which develops into the embryo sac. A similar condition has been reported by Strasburger for Allium fistulosum and Helleborus foetidus (16). Such a row of four cells is formed in Silphium ( $f g .3 I$ ), as indeed in all the Compositae which have been examined. In the determination of the homologies of the cells thus produced, as well as that of the original hypodermal cell, the reduction 
division is certainly to be regarded as a valuable factor. Considering it, for the moment, as of primary importance, the cell in which it occurs in the ovule is a megaspore mother cell, producing by two successive divisions four megaspores, the innermost of which germinates. The presence of a tapetal cell would be determined, not by its size or shape, but by its being cut off before the reduction division occurs.

Many botanists, however, look upon the linear arrangement of the four cells, and the entire absence of any internal cell division in their formation, as serious objections to this view, and prefer to call each of the four a spore mother-cell, of which the fertile one develops directly into the megaspore. This would make each of the four cells in a form like Silphium the homologue of the single fertile cell of Lilium. But to the writer, the linear arrangement of the four cells finds a parallel in the "zonate" method of division in the tetraspores of some Rhodophyceæ; and it seems but natural that a process of "rejuvenescence" should be abandoned in the development of a spore which is not to be shed, but germinates in situ. The condition found in Lilium would then be but the extreme abbreviation of the story, the archesporial cell itself developing into the megaspore.

The successive stages in the development of the megaspore, accompanied by the destruction of the potential megaspores, are shown in figs. $3 I-37$, and present no essential deviations from the process as ordinarily described. The megaspore encroaches but slightly upon the cells of the chalazal region, apparently finding less resistance to growth in the opposite direction. This results in a stretching of the cells of the nucellus, which consists of but a single layer of cells, the epidermis, surrounding the row of megaspores; and finally the rupture of the nucellus ( $\left.f g .3^{6}\right)$, part of which may be carried downward on the tip of the growing sac $(f g .37)$. The greater part of the sac, from this time on, lies free in the space between the funiculus and the integument. At its base may usually be seen the remnants of the broken nucellus. 
The amount of protoplasm in the developing sac is comparatively small, frequently resulting in the presence of very large vacuoles. It will be seen also that the enlargement of the sac, the division of its nuclei, and the destruction of the surrounding cells, do not proceed at the same rate. Thus, in fig. 34 the two nuclei have not left their position in the central strand of protoplasm in which they were formed, while there is no trace of the potential megaspores, and the nucellus is stretched almost to the point of breaking; in $f i g .35$, on the other hand, the nuclei are already widely separated, whereas the sac itself is smaller than in fig. 34 , the remains of the potential megaspores are still recognizable, and the nucellus itself is in a fairly good condition.

The structure of the mature embryo sac may perhaps best be described by taking that of S. integrifolium as a type, and comparing the other species with it. As shown in fig. 38 , the sac is several times longer than was the nucellus. It attains its greatest diameter at about one third of the distance from its micropylar end, and from this point it tapers quite uniformly toward the antipodal region. The egg apparatus occupies about the outer quarter of the sac. The synergids (sy) always lie, the one anterior to the other, in one side of the sac, the opposite side being occupied by the oosphere $(0)$, which is attached well up toward the apex of the sac. It is quite common for each synergid to have a large vacuole in each end, with the nucleus lying between them. In fig. 38 the egg lies above the synergids, almost covering one of them, whose projecting margin is shaded deeply for the sake of distinctness. The reconstruction of the drawing from adjacent sections also made it necessary to represent the vacuoles and nuclei of the synergids as if showing through the protoplasm of the egg.

The oosphere shows a large vacuole in its broad upper portion. Its nucleus is larger than those of the synergids, and contains a very fine chromatin network in resting condition, and a large and often vesicular nucleolus. After the fusion of the polar nuclei, which occurs near the middle of the sac (fig. 37), the primary endosperm nucleus approaches the egg apparatus, 
and is frequently to be found crowded close into the angle between the egg and the synergids, as in fig. 38. It is much larger than the egg nucleus, but in other respects resembles it quite closely. Its nucleolus usually contains one large and several smaller vesicles. The body of the sac is occupied by a large vacuole.

The antipodal cells are generally three in number, separated by walls and arranged in a row, the innermost being much the largest. The Compositae have long been known to exhibit great variability in the antipodal region, a multiplication of cells and nuclei being reported in Senecio aureus by Mottier (20), in Aster and Solidago by Martin (I9), and in Aster Nove-Anglie by Chamberlain (23). The same variability has been seen, to a certain extent, in Silphium, in all the species studied. The wall may be lacking between two of the three nuclei, giving but two cells (fig. 39), either or both of which may show strong indications of direct nuclear division. Again, the nucleus may divide in any one of the three cells (figs. $40,4 I$ ). Finally, in one case, seven antipodal cells were found, containing eight nuclei, with indications of amitotic division ( $f g .42)$.

In a recent paper by Mlle. Goldflus $(\mathbf{2 6})$, already referred to, it has been shown that the antipodal cells in the Compositae possess at times a digestive function, and in other forms serve to conduct food from the ovule to the growing sac with its embryo. All the evidence goes to show that in Silphium these cells are conductive, rather than digestive. It is equally clear that in those forms where the antipodals burrow back into the chalazal region, a fact which may perhaps be correlated with the reduced size of the nucellus, the surrounding cells must be destroyed by the action of a ferment secreted by the cells of the encroaching tissue. The possession of either of these functions is claimed by the author to be inconsistent with the interpretation of the antipodal cells as a vegetative or prothallial region of the gametophyte. But it must be admitted that the most natural function of the vegetative, as distinguished from the reproductive, region of a prothallus, is that of nutrition, of which digestion and 
conduction are but two important phases. The view that the antipodals are homologous with the vegetative portion of a pteridophyte prothallus is strengthened, therefore, rather than overthrown by the discovery of the rôle which they play in the nutrition of the embryo sac.

I have reserved one feature in connection with the egg apparatus for a special consideration, namely, the peculiar cap which is usually to be found upon the micropylar end of the sac. Its ordinary appearance is as in $f g .38$. It is frequently striated, and always shows a rift or superficial groove, which cannot be related, however, to the line of contact between the synergids. The material of which the cap is composed stains deeply with all the stains used, but when lightly stained the outline of the tip of the sac can be seen within it, showing that the cap is not a part of the synergids. This fact precludes the possibility of its being a filiform apparatus, and I have been led to the conclusion that the cap represents the remnant of the nucellus, which may often be broken in pieces, as in fig. 37 , but which, in most cases, is pushed forward by the sac and remains perched, calyptralike, upon its apex. This explanation was first suggested by the form of the nucellus tip (see especially figs. 32, 35), and seems to be the only possible interpretation of the condition seen in fig. 43 , where the cap has evidently continued its growth and become highly vacuolate. Finally, in fig. 44, from a preparation poor in other respects, the cap consists of four cells in section, the walls and two of the nuclei still being visible.

The above description of the embryo sac of Silphium integrifolium will apply very well to $S$. trifoliatum, $S$. terebinthinaceum, and S. laciniatum, the chief differences being in matters of size and proportions, and hardly deserving special mention. The peculiarities of the antipodal and micropylar regions are illustrated from $S$. integrifolium, because its greater abundance, together with its being easier to kill and section, encouraged a more extended study. But abundant evidence was obtained showing that the same peculiarities exist in the other species, 
and their apparently greater uniformity is probably due to their having been less fully investigated.

$S$. perfoliatum presents a type of sac quite different from the other species studied ( fig. 45). In size it agrees quite closely with $S$. trifoliatum, these two species having larger sacs than the other three. The synergids are of a form peculiar to this species, and resemble more closely those figured for other Compositae. They are slender and pear-shaped, usually without vacuoles, and with the nucleus near the inner end. Their outer ends are long, and filled with a very deeply staining protoplasm. Their outline can be followed very easily inside the membrane of the sac, thus affording indirect evidence in confirmation of the claim that the cap found upon the tip of the sac in the other species is not a part of the synergids, but lies outside the sac.

No attempt has been made to do cytological work in the embryo sac, as the difficulty of fixing the material quickly, due to the hard tissues of the ovary wall, rendered practically unavoidable an amount of shrinkage which, though slight, was sufficient to blur the finer cytological details. The general appearance of the oosphere and primary endosperm nucleus has already been described. The drawings are not intended to do more than to show the structure of the nuclei more or less diagrammatically. There is evidence that the egg nucleus leaves the resting condition before fusion with the male nucleus occurs.

The primary endosperm nucleus in $S$. integrifolium has an average diameter of $\mathrm{I}_{5} \mu$, its nucleolus being $6-8 \mu$; the oosphere nucleus averages $9 \mu$ in diameter, with a nucleolus of $3 \mu$. The sac itself is about 220 by $40 \mu$. In $S$. perfoliatum the endosperm nucleus measures $26 \mu$, its nucleolus I $2 \mu$; the egg nucleus $17 \mu$, its nucleolus $6 \mu$; the sac itself, about 300 by $65 \mu$.

\section{DEVELOPMENT OF MICROSPORES.}

When the young stamen has reached the stage shown in fig. 7 , the hypodermal archesporial row is distinguishable from the surrounding tissue by the increased size of its component cells and their different staining reaction. A transverse section of 
such a stamen shows that its anther is already fusing with those of the other stamens in the flower. In each corner of the anther a single large hypodermal cell is found (fig. 46), which soon divides into an outer and an inner cell, which may be called, respectively, the primary tapetal and primary sporogenous cells. If we bear in mind that Goebel applies the term archesporium to the row which we have called primary sporogenous, his statement (Outlines of Classification, etc., p. 363) that in the Compositae the archesporium consists of a single row of cells finds here an easy confirmation ( $f i g .47)$.

Periclinal walls soon appear in the primary tapetal row, by which it becomes a cell layer. This soon divides into two layers $\left(f g .4^{8}\right)$, of which the inner is to become the external portion of the tapetum, while the outer divides again to form the "endothecium" and the "middle layer" ( fig. 49). The tapetal layer is completed by the addition of cells lying between the sporogenous mass and the connective, the whole layer finally consisting of large and usually binucleate cells with densely granular contents. The layer of cells just behind this addition to the tapetum grows to resemble the middle layer, thus completing a second nutritive layer $\left(\mathrm{fg} . \mathrm{5}^{\circ}\right)$. It will be seen that the foregoing account of the origin of the sporogenous cells and their surrounding layers agrees with the early work of Warming.

Meanwhile, longitudinal divisions have occurred in the primary sporogenous row, giving finally a mass of four or five cells in cross section. The appearance of the various layers in longitudinal section is also shown, fig. $5^{I}$ corresponding quite closely to $f i g .47, f i g .52$ to $f g .49$, and fig. 53 showing a stage just younger than fig. 50 . A comparison of figs. 52 and 53 shows that the rule that when the tapetum is differentiated the pollen-mother-cell stage has been reached is not of such universal application as Guignard claims for it (18). Exception to this rule has already been noted by Miss Lyon in Euphorbia (26). That the sister layer to the tapetum divides to produce the endothecial and middle layers is shown at $x$, figs. 49,52 . This division may not occur at all, and in such cases the original 
layer forms the endothecium, which then lies next to the tapetum, as in fig. 54 .

At the time of their first division, the pollen mother-cells are lying free in the cavity of the sporangium, and are perfectly spherical in form. The division occurs simultaneously in all the mother cells in a loculus, and it can frequently be noticed that the two outer loculi are slightly in advance of the inner ones of the same anther. For example, when the spindles in an inner loculus are in an equatorial plate stage, as in fig. 54 , daughter stars will be found in the mother cells of the outer loculus. As may be seen from the figure just cited, the chromosomes are nearly spherical, and it is very easy to count them, as the spindles lie in all possible directions. In favorable preparations the number eight can be counted repeatedly, even with a comparatively low magnification. Reference has already been made to this as being the reduction number found in the development of the megaspore.

The rapidity with which the second division follows the first may be inferred from the fact that even in the same loculus mother cells may be found, some of which show daughter stars of the first division, while in others one of the daughter nuclei may already have formed the spindle for the next division. The two spindles generally lie across each other, as in fig. 55, but they may sometimes be side by side.

We may take figs. $54,56,57,58$, as showing the stages which may be found in four adjacent flowers along a radius of the head. The spines of the pollen grain appear soon after it is set free from the tetrad. For a time the spore exhibits a large vacuole, but this soon disappears.

While these changes have been taking place the tapetum and middle layer have been disorganizing. In this way a plasma is formed which gradually distributes itself among the pollen grains. The nuclei of the disorganized cells are visible for quite a long time. This plasma finally collects around the spores (fig. 59), and is at last encrusted upon them as a sheath ( $f g .62)$, exactly comparable to the perinium of a pteridophyte spore. 
THE MALE GAMETOPHYTE AND FERTILIZATION.

The pollen germinates in the anther. Three or four places for the exit of the pollen tube are present, and at the time of dehiscence the contents of the spore can be seen protruding slightly from each of them. The two nuclear divisions by which the vegetative and generative nuclei, and the two sexual nuclei, arise, were not followed; but the difference in size and staining reaction in the stages found indicate that there is no deviation from the process as ordinarily described. The generative nucleus $(g, f i g .59)$ is soon surrounded by a small quantity of hyaline cytoplasm, distinguishable from the more granular protoplasm of the rest of the spore. The nuclei of the two sexual cells $(m, f i g .60)$ are smaller than the vegetative nucleus. At this stage practically no structure can be made out in any of the nuclei. The male nuclei usually stain less deeply than the vegetative nucleus.

When first formed the male nuclei are approximately spherical, as in $f i g .60, m$. But in later stages their form undergoes a very remarkable change. The nucleus begins to be drawn out at one end, and soon becomes very much elongated. During this process the two nuclei generally lie side by side, and may finally become so long as to reach fully half way around the interior of the pollen grain. Some of the stages are shown in figs. $6_{1}, a-f, 6_{2}, 6_{3}$. It will be seen that the somewhat sinuous form generally assumed frequently resolves itself into a spiral ( $f i g$. $6 I, d, e)$. This change of form was found in three of the species studied, S. integrifolium, S. terebinthinaceum, and S. perfoliatum, and might possibly have been discovered in the other two had they been as thoroughly investigated upon this point. The structure of the nucleus was very difficult to make out, since, in sections less than го $\mu$ in thickness, so long a body was likely to be cut in pieces; and with this thickness of section the pollen grain would be cut through but once, and the nuclei were seen against a background of deeply staining spore wall. With the most favorable light the nucleus can be seen to consist of a network with extremely fine meshes. The surrounding film of 
cytoplasm is not always visible. Fig. $61, f$ shows as nearly as possible the appearance of the fully developed male cell, and brings out also the fact that the sinuous or spiral form is finally lost, and the nucleus is merely slightly bent.

Strasburger and others have figured somewhat elongated male cells in various plants, but no more than could be explained by the need of such a form in order to pass down a slender pollen tube. In one account, that of Golinski (2I), the male cells of Triticum and other Gramineæ were described as being " not at all unlike an antherozoid of the Characeæ or ferns." $\mathrm{He}$ even records the presence of a vesicle, persisting for some time in a loop of the sex cell. Nothing of this kind occurs in Silphium, but, judging by the figures given, the spermatozoid form is here far more pronounced.

Until recently, Golinski's account was the only one which offered any parallel to what has been found in Silphium. Such an association of a composite with the grasses would seem at first to be an absurdity. But it is not a new one, for the Gramineæ stand preeminent among the monocotyledons as the formers of tissue by the antipodal cells, as do the Compositae among the dicotyledons; and if the antipodal cells represent a prothallial region, there is thus a primitive character in the female gametophyte of both groups, matched now by the peculiar form of the male cells.

Nawaschin's recent announcement (28) of long, vermiform male nuclei in Lilium Martagon recalled a figure published last year by Mottier (25), showing a coiled male nucleus lying against the female pronucleus. Fuller confirmation of Nawaschin's preliminary statement has already come from Guignard (29), who not only has given us excellent figures, but has extended his observations to several other species of the Liliaceæ. The male nuclei, as he figures them, resemble closely those of Silphium. Their fusion with the polar nuclei, reported by both Nawaschin and Guignard, has not been found in Silphium, which, by virtue of the earlier formation of the definitive nucleus, is not a favorable object for the study of this point. 
These recent investigations prove that the occurrence of spermatozoid-like male cells in Angiosperms is not so rare as was once supposed.

The pollen tube passes along the outside of the cap which usually crowns the embryo sac ( $f g .64)$, and enters the sac just beyond its free margin. One of the synergids now begins to disorganize, and soons becomes unrecognizable. The other usually persists for a considerable period, lying against, or partly covering, the suspensor of the young embryo. When seen in side view this might easily be taken for a pollen tube, as in fig. 66, for example. But a little familiarity with the type soon removes this source of error, as the pollen tube is much more slender. Where the synergid can be seen passing up within the cap, as in $f_{i g} .67$, there is no chance for uncertainty as to its identity. That neither of the synergids may be disorganized until fertilization is accomplished is shown by $\mathrm{fig} .65$.

The recent accounts of fertilization in Lilium, already cited, suggested that a careful study of the behavior of the spiral male cells of Silphium would be very desirable. Unfortunately, the most favorable preparations showing male pronuclei in the oosphere were in S. laciniatum and $S$. trifoliatum, the two species in which the elongated cells were not found. Preparations of the other species, showing the nuclei in the tip of the pollen tube, indicate that the sex nuclei have resumed a spherical form. By the growth of the male pronucleus it acquires a close resemblance to the egg nucleus before fusion occurs.

\section{DEVELOPMENT OF THE EMBRYO.}

After fertilization the oospore develops a wall, and elongates rapidly. Its proximal end is occupied by a large vacuole, while its distal end is filled with a mass of protoplasm containing the nucleus.

The first wall in the oospore is transverse, as usual, and separates a large proximal vesicular cell from a smaller terminal cell. It will be of interest to note that the primary endosperm nucleus divides before the first wall appears in the oospore 
(fig. 65). The early divisions of the endosperm nuclei occur more rapidly than those in the embryo, for while there are yet but two cells in the embryo, the endosperm nuclei have passed to their third division, a condition shown in fig. 66. The antipodal cells are still to be seen in a small pocket at the extremity of the sac. Their final disappearance does not occur until a considerably later stage.

It is customary to speak of the cell which produces the octants as the embryo cell, and of all the remaining cells as belonging to the suspensor. The term is never strictly accurate, for even in such cases as Capsella the dermatogen and periblem of the root are contributed by the cell below the octants. Again some authors, noticing that the first wall in this "embryo cell" is usually longitudinal, conclude that, conversely, the first longitudinal wall identifies the embryo cell - a definition which breaks down in cases where the octants are formed by a transverse wall followed by two longitudinal walls, as has been claimed by Schwere (24) to be the rule for Compositae. If, however, we give to the term "embryo cell" a uniform signification, namely, the cell which produces the octants, we shall at least justify its use as a term of convenience.

Another term of varied application is the word hypophysis, or "Anschlusszelle." In Hanstein's account of the embryo of Capsella (2), the cell next below the octants divides by a transverse wall, and its upper half divides again to form the "Periblem-schlusszelle" and the "Dermatogen-schlusszelle," ${ }^{x}$ the latter, by repeated splitting, forming the layers of the root cap. Hanstein applies the term hypophysis sometimes to this original suspensor cell, at other times more particularly to its upper half, thus designating as the "Anschlusszelle" the cell which actually completes the embryo. On the other hand Schwere, for example, applies the term to the cell which is, next below the embryo cell, indeed, but which only partially

"Throughout the rest of this account the rather cumbrous words "Dermatogenschlusszelle" and "Periblem-schlusszelle" will be translated by the terms dermatogen and periblem terminals, respectively. The fact that they later become the dermatogen and periblem initials need cause no confusion when the latter terms are substituted. 
corresponds to the cell similarly placed in Capsella; for in Taraxacum this cell produces only concentric layers of dermatogen and periblem, a second suspensor cell doing the same thing, while the root cap is formed by the third cell from the embryo cell. In such a case, the term hypophysis, as applied to a single cell, could be justified only by proving that these three cells arose by the division of an original single cell next to the embryo cell. This, however, has never been done.

As a further preface to the discussion of the development of the embryo, it may be well to state that in the early part of the work the entire ovary was cut longitudinally in the plane of the radius of the inflorescence, in order to determine with certainty the direction of the early divisions in the embryo. Later, the ovules were dissected out, and the direction of the section, whether in the radial or tangential plane, was ascertained from the position of the funiculus.

Passing on now to the second division in the young embryo, we see by fig. 68 that the two nuclei present may prepare for division at almost exactly the same time. The nucleus of the terminal cell is slightly in advance of the other, as the segmentation into chromosomes has occurred, and the nuclear membrane has disappeared. However, the difference is so slight that we are left without absolute proof as to the origin of such a stage as fig. 69. If the terminal cell alone has divided, two interpretations are possible. First, a transverse wall may have arisen in the embryo cell, in which case my figs. 69, 70, 71 would correspond exactly to Schwere's figs. 8, 9, a, 9, respectively, as fig. 70 is cut in the radial plane and $f g .7_{I}$ in the tangential. The second possibility is that the terminal cell in fig. 69 is the real embryo cell, but marked out by the second division in the oospore; and a comparison of figs. 69, 70 with $72-76$ shows that this is actually the cell which produces the octants. This being true, we may now apply the term embryo cell definitely to the terminal one of the three cells in $f g .69$. It would be an obvious error to give that name to the terminal cell of fig. 67 , for, according to this interpretation, the latter cell produces 
more than the octants. I shall attempt to show that the middle cell of fig. 69 contributes to all the primary tissues of the embryo, but to change the accepted definition of the embryo cell on this account would result in needless confusion.

A third possible origin for fig. 69 is that the vesicular cell of fig. 67 may have divided first. This is not exactly in line with fig. 68 , but should be recognized as a possible, if not a necessary interpretation. According to this view, the terminal cell of figs. 67 and 68 would be the same as that of fig. 69 , and Silphium would agree with other Compositae in having the embryo cell marked out by the first division of the oospore. In the lack of positive evidence on this point it is perhaps best to let this stand as the correct interpretation, at the same time recognizing the possibility that the real embryo cell may be but one of the daughters of the terminal cell of fig. 68 .

The first wall in the cell producing the octants, or as we may now call it, the embryo cell, is longitudinal, and in the radial plane of the head (figs. $70,7 I$ ). As the cotyledons of the mature embryo occupy an antero-posterior position in the ovary, it will be seen that this wall does not separate them, but rather cuts each one in two. The cotyledons are not separated until the second series of divisions, in the tangential longitudinal plane, has occurred $(f i g .72)$. Fig. 73 shows an embryo in which the transverse walls followed the first longitudinal, or may even have appeared first; but of this latter there is no proof.

The formation of the octants is soon completed ( fig. 74), usually by a series of transverse walls in the quadrants of fig. 72 . The upper octants divide more rapidly than the lower four, and as the two sets differ considerably in their mode of development, it will be easier to treat them separately. We may then go back to trace the development of the cells below the octants.

The first walls in the upper octants are, in most cases, a set of anticlinals. Fig. 75 shows an embryo with this first anticlinal wall in one of the upper octants. The other three are not yet divided. All of the figures up to and including this one are of whole embryos, with all of the nuclei shown. The remaining 
figures are of sections. Fig. 76 shows one half of an embryo in which all four upper octants have divided. Of the two shown in the figure, the left one has cut off the dermatogen by a periclinal wall, while the right one shows the usual anticlinal wall. The other two of the four show in the adjacent section of the series, each with an anticlinal wall, as in $f i g .77$, which is drawn from another embryo in nearly the same stage. These anticlinals may intersect either of the primary, or octant, walls, and sometimes, by their early shifting, one may be in doubt as to which wall really separates the octants $(e . g ., f i g .78)$.

The dermatogen is usually cut off by the second series of walls in each upper octant (figs. $78,8 I$-right, 82 -left). In octants where the first wall was periclinal, differentiating the dermatogen, the second wall is usually an anticlinal, in the inner of the two cells by the first division ( $f i g .8 I$-left). The next walls generally occur as a series of periclinals, giving three concentric layers of cells in the upper octants, as in fig. 83. The regularity in this part of the embryo is soon lost, and there arises a mass of parenchymatous tissue in which division may occur in any direction. By repeated anticlinal divisions the dermatogen grows to keep pace with the increase in the bulk of the tissue beneath it.

When each upper octant has undergone its first division, the four lower octants are still undivided (figs. 76, 77). The dermatogen is cut off here by the first walls ( figs. 78, 79). The second division is probably always in the inner cell, thus separating periblem from plerome. Fig. 79 (left) is not conclusive on this point, but fig. 84 , in which a series of transverse walls has arisen, shows at the left that periblem and plerome cells arise by the division of an original inner cell. As a result of these divisions three concentric layers of cells are formed in the hypocotyledonary part of the embryo, as is shown in figs. $80,8 \mathrm{I}$.

While the primary tissues are thus being differentiated, the cells of the lower octants are becoming considerably elongated ( figs. 78-8I); and soon a series of transverse walls appears, by which two similar tiers or layers of cells are formed, as shown 
in figs. 82-85. Before this last process is completed, the plerome cells may begin to divide into an inner and an outer layer, as seen in the left lower octant of fig. 86. This makes the plerome of this region consist of two concentric layers of cells, a condition shown again in figs. 89-9I. In fig. $9 I$, at the left, the outer of these layers is again splitting in two.

We must now return to the consideration of the cell below the octants, in order to discover what it contributes to the embryo. Starting with the middle cell of $f i g .69$, it is easy to trace it, with the vesicular cell next to it, through figs. $70-73,75$ and 76 . This cell, or its product, is labeled $c$ throughout the figures. In fig. 74, cell $c$ has divided once, longitudinally. In fig. 75 , judging by the size of the cells, $c$ is undivided, while the vesicular cell has acquired a transverse wall. In this way a varying number of suspensor cells may arise.

The longitudinal wall in cell $c$, shown in figs. 74 and 77 , is soon followed by a second one at right angles to the first, giving a tier of four cells, three of whose nuclei are shown in fig. 79 . In figs. 78 and 82 , periclinal walls have arisen, cutting off an outer dermatogen layer. It will be seen that cell $c$ is undergoing a series of divisions exactly similar to those arising in the lower octants. A second series of periclinal walls, predicted in fig. 86, and incomplete in figs. 83 and 88 , is completed in fig. 89 . In figs. 90 and $9 I$, the innermost of these three concentric layers has split again longitudinally.

The claim of an "addition to the embryo" from the "suspensor" is not a new one. It will be sufficient to cite from two of the more recent papers upon Composite embryology. Mottier (20) finds that in Senecio aureus the cell below the octants contributes dermatogen and periblem to the embryo, the root cap, to judge by his figures, being organized by the next cell. He makes no specific statement upon this point. Schwere(24) finds two "suspensor" cells adding dermatogen and periblem to the embryo of Taraxacum, while the third cell organizes the root cap.

The embryo of Silphium differs from that of Taraxacum in that the product of but one original cell lies between the octants 
and the cell organizing the root cap; it differs from Senecio in that this one cell contributes not only dermatogen and periblem, but also the terminal portion of the plerome.

The possibility that the tier of cells called $c$, in embryos older than that in $f g .77$, arose by the transverse division of the inner octants, has of course presented itself. But in such a case the cells above and below the dividing walls would show clear indications of their being thus related, and the two tiers would be symmetrical as to number and position of cells on either side of the dividing line. Such a symmetry is illustrated in the lower octants of figs. 82 and 85 , where two tiers of cells are in a process of separation. But no such symmetry is to be found between tier $c$ and the tier above it, in any of the figures on plate $V$. These two tiers proceed at very different rates of growth, as a comparison of figs. 78 and 85 or 86 plainly demonstrates. Moreover, in the study of such a stage as $f i g .79$, the longitudinal walls separating the octants are, we may say, in the plane of the paper and perpendicular to it, respectively; whereas the corresponding walls in tier $c$ always run in different planes, being frequently inclined as much as forty-five degrees to the longitudinal walls in the octants. These facts prove conclusively that tier $c$ has an origin independent of the octants, and that the description of its ultimate fate, as already given, is correct.

There yet remains for us the consideration of the origin of the root cap. This point seems to have suffered from a general neglect. Hofmeister (I) gives a short description of Helianthus, but no detailed study of the sequence of cell divisions was made.

The first account giving any reliable data upon the point in question is that of Hanstein (2), whose description of the process in Capsella has already been mentioned, and is too familiar to need repetition. In a second mode of cap origin, described for Enothera, a lenticular cell is cut out from the upper surface of the hypophysis cell, and becomes the periblem terminal; while the remaining portion produces the dermatogen of the root, by the splitting of which the cap arises. Hanstein does not describe any Composite embryos. 
Reinke (3) treats of the structure of the root tip in later stages, but not at the time of the first appearance of the cap. $\mathrm{He}$ reduces the roots of all phanerogams to one type, that found in Helianthus, with separate initials for plerome, periblem, and dermatogen, the latter proliferating to form the cap.

Fleischer (6) describes a mode of cap origin identical with Hanstein's Capsella, but gives no figures. His account derives the cap from the cell next to the octants, differing in this respect from all other descriptions of Composite embryos. In the structure of the older root tip he agrees with Reinke.

Janczewski $(\mathbf{4}, \mathbf{5})$ confines his attention to older roots, and distinguishes four types of root-tip structure, one of them being the "Helianthus type." He claims, however, that the cap does not arise by the splitting of the dermatogen, but that the inner layer of the root cap is a "calyptrogen," which later abandons its protective function and becomes the epidermis. Later authors have assigned various plants to the "Helianthus type," without noticing that their description agreed with Reinke's account, rather than with that of Janczewski. The validity of the Helianthus type is not to be questioned, for these two views are really but two different interpretations put upon the same structure, Reinke's view having been adopted by all the later writers as the more natural one.

Holle (8) claims that the Helianthus type is the characteristic one for dicotyledons, and that all other types are mere variations. The primary origin of the root cap is not discussed.

In the embryo of Senecio aureus, according to Mottier (20), the cell below the octants divides first by one or two transverse walls, and the resulting cells divide longitudinally, adding dermatogen and periblem to the embryo. The cap is probably formed by the next cell below, that is, by the second "suspensor cell."

Maxwell (22), although doing no work upon the Compositae, has given us one of the best reviews, in English, of the work of these earlier writers.

Schwere (24) finds that in Taraxacum the first and second cells of the suspensor add dermatogen and periblem to the 
embryo. A third cell divides transversely, its inner half completing the dermatogen and its outer half becoming the first layer of the root cap.

It was seen very early in the course of the investigation that Silphium did not follow the process found in Capsella, and described by Fleischer for Helianthus. Nor could the stages found be made to agree with Schwere's Taraxacum embryos. The mode of origin of periblem and dermatogen terminals resembles more nearly the process as found by Hanstein in Enothera, the greatest difference being in the origin of the periblem terminal. This, instead of being cut out as a lenticular cell from the upper side of the hypophysis cell, is apparently formed by the intersection of three walls, inclined so as to meet the basal wall of tier c. Figs. 86 and 88 partially illustrate this process. The first of these three walls may at first appear to be longitudinal, as in fig. $8 \mathrm{I}$, but it is plainly oblique in $f i g .86$. In $f i g .88$ the second oblique wall is shown, and a third nucleus, in the tier below the periblem terminal, but in another focus, gives proof of the presence of a third dermatogen terminal.

In $f i g .89$ the periblem terminal has divided by probably two longitudinal walls, giving a plate of four cells. In fig. 90 , by a shifting of the cells, the periblem terminals have been drawn still farther into the pear-shaped body of the embryo. Another wall in the dermatogen terminals gives three cells in section, the middle one being quite broad. In $f g .9 I$ the two lateral dermatogen terminals have split to produce a layer of the cap; and the presence and direction of the spindle in the middle cell furnishes conclusive proof that the root cap arises by the splitting of the dermatogen. Fig. 92 shows a portion of a much older embryo, seen entire in fig. $92, a$. The relations of the primary tissues are the same as in fig. $9 I$. The boundaries between plerome and periblem are made heavy, and the epidermal cells are drawn with nuclei. The greater thickness of the cap at the end of the embryo is caused by the splitting of the layers of the cap itself, as can be seen clearly in several places. The apparent diminution in the size of the cells is almost entirely due to the 
fact that the magnification of $f g .92$ is but two thirds of that of fig. 91 .

At this time the cotyledons are nearly half as broad as long, and the tissues of the ovule are reduced to a thin sac, loosely covering the embryo. Ample protection for the growing embryo is provided by the hard walls of the ovary. Older stages of the embryo were not studied, as the increasing hardness of the ovary wall made the rapid fixing of the ovule and embryo more and more difficult.

\section{SUMMARY AND CONCLUSIONS.}

In the general features of its development, the foregoing account of the life history of Silphium agrees with those of the other Compositae. But so many facts are peculiar to the genus, that a résumé of the course of development is necessary, and a comparison with other Compositae.

The flowers of Silphium in their adult form are of two kinds, the disk flowers being staminate and sterile, the rays being fertile and without stamens.

The order of development of floral organs in the disk flower is corolla, stamens, carpels, calyx. The nectary appears just before the pappus. There is never any trace of ovary or of ovule. The pappus is almost entirely wanting.

The floral organs of the ray flower, in the great majority of cases, appear in the same order as in the disk. The stamens almost always remain as mere papillae, but a few flowers were found in which they had formed pollen mother-cells. The ovary is formed as a cavity between the carpels. The ovule is terminal and cauline, as is shown by its position and bundle relations. This claim is not in accord with the other special accounts for Compositae, but agrees with the claim for a primitive cauline ovule in this family, made recently by Campbell (30). Proofs for this claim, however, are first presented in the present paper.

In that the hypodermal archesporial cell develops a row of four potential megaspores, of which the inner one germinates to form the embryo sac, Silphium resembles all the other 
Compositae which have been described. Eight chromosomes were counted in the megaspore mother cell. The number has not been reported for any other genus.

Four of the five species studied-S. integrifolium, S. trifoliatum, S. terebinthinaceum, and $S$. laciniatum-resemble each other in the general structure of the embryo sac. The synergids and oosphere are somewhat pear-shaped, the egg being inserted near the apex of the sac. The polar nuclei fuse before fertilization, and the definitive nucleus lies near the egg apparatus. The antipodal cells are arranged in a row, and, as is common among Compositae, tend to increase in number beyond the original three. The growing sac quickly ruptures the nucellus, and the basal portion of the latter is to be found as a remnant by the side of the antipodal cells. The terminal portion generally remains perched on the apex of the sac, forming a densely staining cap. In one case these nucellar cells had continued their growth in this position. Such a nucellar cap is new for Compositae, but has been reported in various aroids by Campbell (30) and others.

The embryo sac of $S$. perfoliatum is like that of the other species in most respects, but presents a very different appearance in its micropylar portion. There is no nucellar cap. The synergids are very much elongated, their tips being filled with a very dense protoplasm. They do not, however, rupture the tip of the sac.

The development of the microsporangia follows the wellknown order, the steps of which need not be repeated. By the failure of the last series of divisions, the middle layer may be lacking, the sister layer to the tapetum in this case developing into the endothecium. The sporogenous cells divide at least once after the tapetum begins to take a differential stain.

The nuclei of the pollen-mother cells show a well-marked synapsis stage, and pass quickly from this to the formation of the spindles for the first division. In the equatorial plate of this spindle the reduced number of chromosomes, eight, was repeatedly counted. The second division follows immediately after the first. 
The division of the nucleus of the pollen grain into a vegetative and a generative nucleus, and the division of the latter into two sexual nuclei, apparently follows the usual order. The male cells are at first round, but in three of the five species examined they become greatly elongated, often acquiring a remarkably spermatozoid-like form. Such a form of male cells has been reported among various monocotyledons, but up to the present time Silphium is the only dicotyledon reported as showing them.

The pollen tube enters the embryo sac just beyond the edge of the nucellar cap. Fertilization may be accomplished without the previous disorganization of either of the synergids. The division of the definitive nucleus precedes the division of the oospore.

The first wall in the oospore is, as usual, transverse. It is possible, though not certain, that, unlike the other Compositae described, the terminal cell of the two-celled stage divides again transversely, and that the real "embryo cell" is the outer cell arising by this second division.

The first wall in the embryo cell is a radial longitudinal one, instead of being transverse, as is said to be the rule for Compositae. The second or quadrant wall is likewise almost always longitudinal, and separates the two cotyledons. The transverse walls separating the octants are the third series to appear.

The first series of walls in the outer octants is oblique, the dermatogen being cut off by the second series. In the inner octants the first walls differentiate the dermatogen, and the inner cells divide again to produce the periblem and plerome.

The cell below the octants, cell $c$, by divisions exactly similar to those in the inner octants, forms a tier of cells which adds to all the primary tissues of the embryo.

The periblem terminal is formed by the intersection of three oblique walls in the cell next below cell $c$. The other daughter cells in contact with the periblem, terminal complete the dermatogen of the root, and by splitting form the first layer of the root cap. 
The relations of the primary tissues remain unchanged in older embryos. Dermatogen, periblem, and plerome have separate initials, and the root cap arises by proliferation of the dermatogen. Thus the embryo of Silphium conforms to the "Helianthus type," as described by Reinke.

UNIVERSity OF ROCHESTER, N. Y.

\section{BIBLIOGRAPHY.}

I. Hofmeister, W.: Die Entstehung des Embryo der Phanerogamen. Leipzig. I 849 .

2. Hanstein, J.: Die Entwickelung des Keimes der Monokotylen und Dikotylen. Botan. Abhandl. aus dem Gebiet der Morph. u. Physiol. I : I-I I 2. I870.

3. REINke, J.: Untersuchungen über Wachsthumsgeschichte und Morphologie der Phanerogamen-Wurzel. Botan. Abhandl. aus dem Gebiet der Morph. u. Physiol. 3 : I-50. 187 I.

4. JanCZEWSKI, ED.: Das Spitzenwachsthum der Phanerogamenwurzel. Bot. Zeit. 32: I I 3-I I 4. I874.

5. - Recherches sur l'accroissement terminal des racines de les phanerogames. Ann. Sci. Nat. Bot. V. 20 : 162-202. 1874.

6. Fleischer, E.: Beiträge zur Embryologie der Monokotylen und Dikotylen. Flora $57: 369-375,385-394,40 \mathrm{I}-4 \mathrm{II}, 417-432,433-447$. 1874.

7. Eichler, A. W.: Blüthendiagramme $\mathbf{I}: 285-292$. I 875 .

8. Holle, H. G.: Ueber den Vegetationspunkt der Angiospermen-Wurzeln, insbesondere die Haubenbildung. Bot. Zeit. 34 : 24I-255, 257263. 1876.

9. Warming, E.: De l'ovule. Ann. Sci. Nat. Bot. VI. 5 : 177-266. 1878.

ro. Vesque, J.: Developpement du sac embryonnaire des phanerogames. Ann. Sci. Nat. Bot. VI. $6: 237-285$. 1878 .

Ir. ERIKsson, J.: Ueber das Urmeristem der dikotylen Wurzeln. Jahrb. f. wiss. Bot. II : 380-436. 1878 .

12. Flahault, Сh.: Recherches sur l'accroissement terminal de la racine chez les phanerogames. Ann. Sci. Nat. Bot. VI. 6 : 1-168. 1878.

13. Strasburger, E.: Die Angiospermen und Gymnospermen. Jena, i879.

14. SACHS, J.; Text-book of botany. Eng. transl., 2 d ed. Oxford, I882.

15. GUIGnard, L.: Nouvelles recherches sur le noyau cellulaire et les phénomènes de la division commune aux vegetaux et aux animaux. Ann. Sci. Nat. Bot. VI. $20: 310-367.1885$.

16. Strasburger, E.: Ueber Kern- und Zelltheilung im Pflanzenreiche. Jena, I 888 . 
17. Hegelmaier, F.: Ueber den Keimsack einiger Compositen und dessen Umhüllung. Bot. Zeit. $47: 805-8$ i 2, 82 i $-826,837-842$. i 889 .

18. Guignard, L.: Nouvelles études sur la fécondation. Ann. Sci. Nat. Bot. VII. I4 : I63-2I7. I89I.

19. Martin, G. W.: Development of the flower and embryo-sac in Aster and Solidago. Bot. Gaz. 17 : 353-358, 406-4 I I. I892.

20. Mottier, D. M.: On the embryo-sac and embryo of Senecio aureus L. Bot. Gaz. $18: 245^{-2} 53$. 1893 .

21. Golinski, St. J.: Ein Beitrag zur Entwickelungsgeschichte des Andrœciums und des Gynæciums der Gräser. Bot. Cent. 55 . I-I7, 65-72, I 29-135. I893.

22. Maxwell, F. B.: A comparative study of the roots of Ranunculaceæ. Bot. Gaz. 18:8-16, 4 I-47, 97-102. I893.

23. Chamberlain, C. J.: The embryo-sac of Aster Nova-Anglice. Bot. Gaz. $20: 205-2$ I 2. I 895 .

24. Schwere, S.: Zur Entwickelungsgeschichte der Frucht von Taraxacum officinale Web. Ein Beitrag zur Embryologie der Compositen. Flora $82: 32-66$. I 896 .

25. Mottier, D. M.: Ueber das Verhalten der Kerne bei der Entwickelung des Embryosacks und die Vorgänge bei der Befruchtung. Jahrb. f. wiss. Bot. 31 : 1 25-I 58 . I 898 .

26. Lyon, Florence M.: A contribution to the life history of Eurphorbia corollata. Bot. Gaz. $25: 4$ 18-426. r898.

27. Goldflus, Mathilde: Sur la structure et les fonctions de l'assise épithéliale et des antipodes chez les Composées. Journ. de Botanique I2 : 374-384. I898; 13:9-1 7, 49-59, 87-96. I 899.

28. Nawaschin, S.: Neue Beobachtungen über Befruchtung bei Fritillaria tenella und Lilium Martagon. Bot. Cent. $77: 62$. I899.

29. Guignard, L.: Sur les anthérozoïdes et la double copulation sexuelle chez les végétaux angiospermes. Comptes Rendus 128: I-8. Apr. I 899 .

30. Campbell, D. H.: Notes on the structure of the embryo-sac in Sparganium and Lysichiton. Bot. Gaz. 27 : I 53-166. 1899.

\section{EXPLANATION OF PLATES III-X.}

All the drawings were made with a camera lucida. Figs. $1-27$ and 66 were drawn with a Reichert ocular no. 4 and objective no. 3 ; figs. 59-63 with Reichert ocular I2 and Bausch and Lomb $\frac{1}{12}$ immersion objective; fig. $9^{2}$ with Reichert ocular 2 and Bausch and Lomb $\frac{1}{12}$ immersion objective; all other figures with Reichert ocular 4 and Bausch and Lomb $\frac{1}{12}$ immersion objective. The original magnification will be specified for each figure. The plates are reduced to three eighths of the original size. 


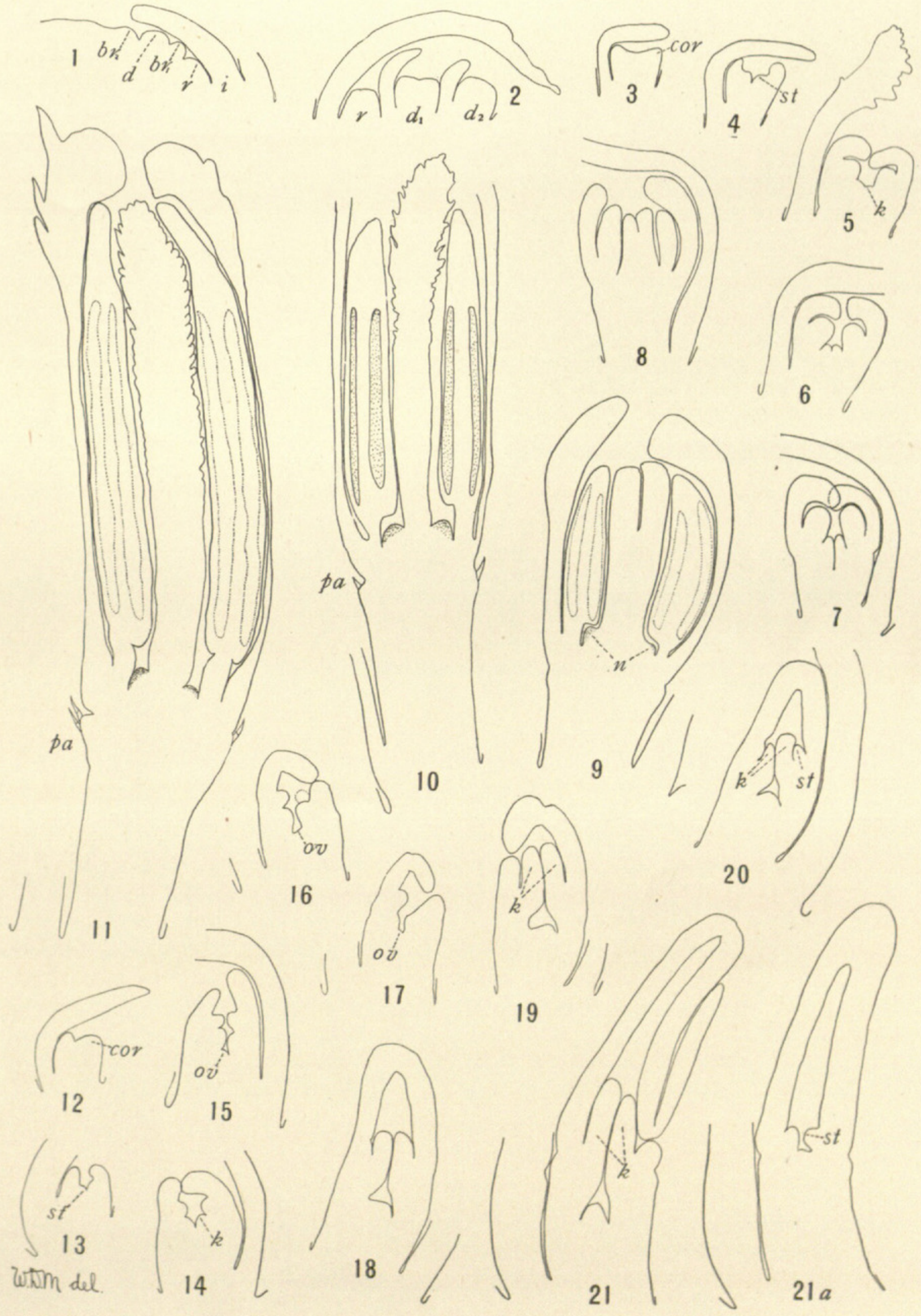

MERRELL on SILPHIUM 


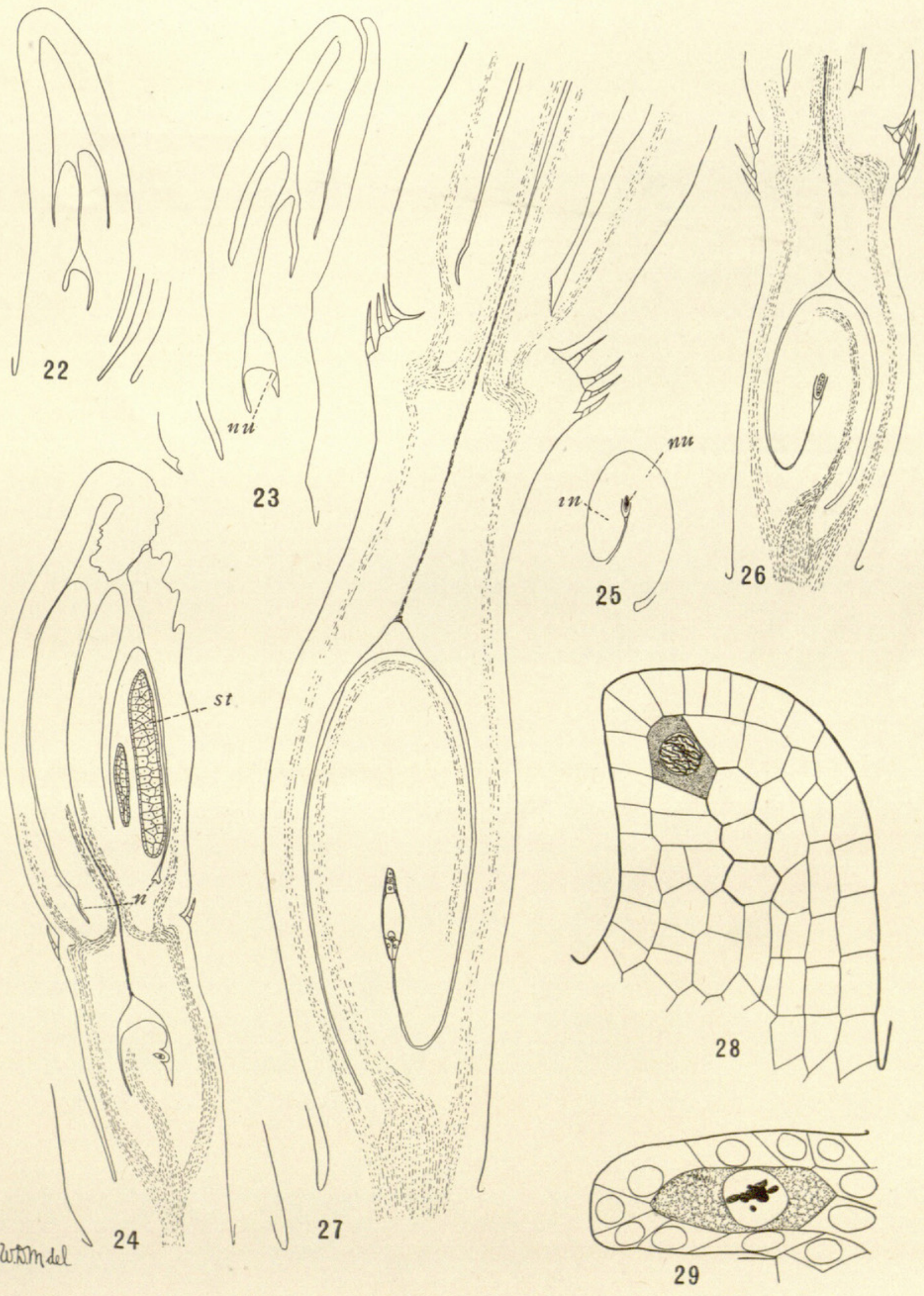



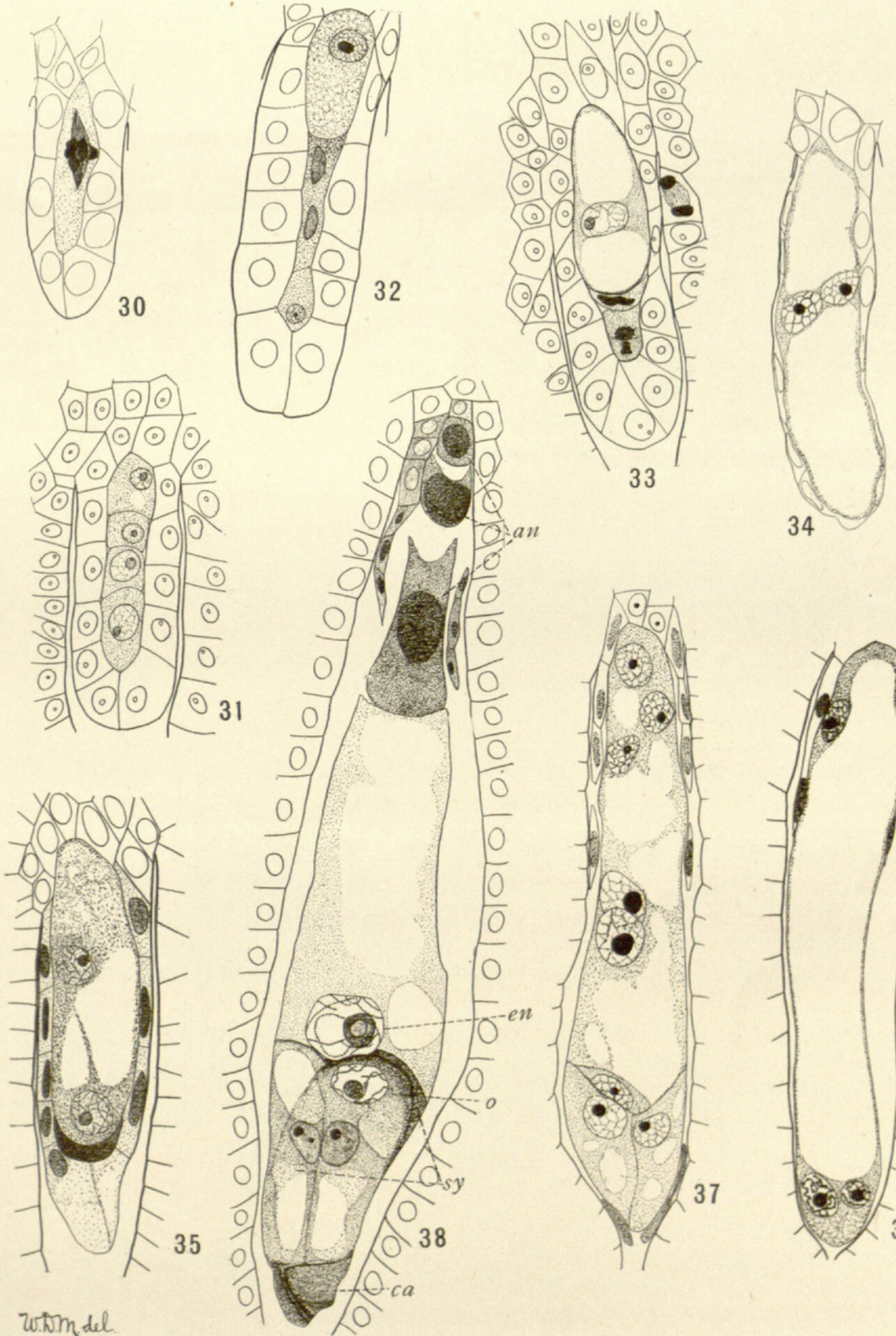

wotomdel

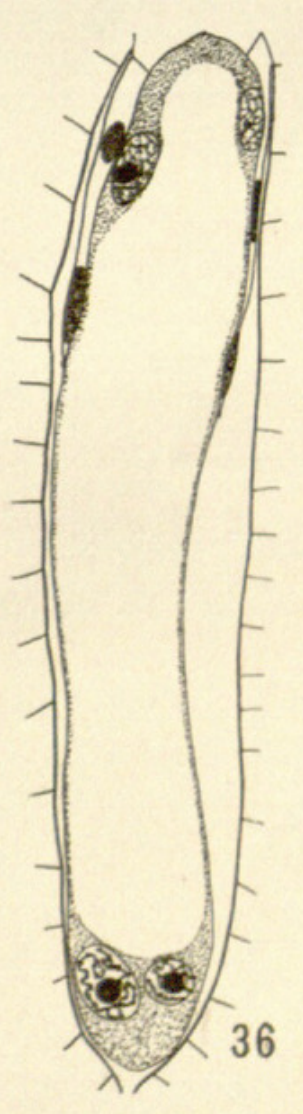



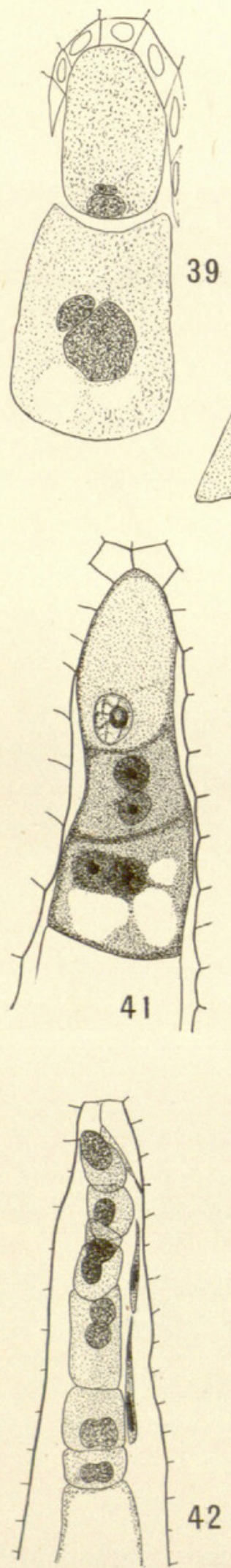

Worto. del

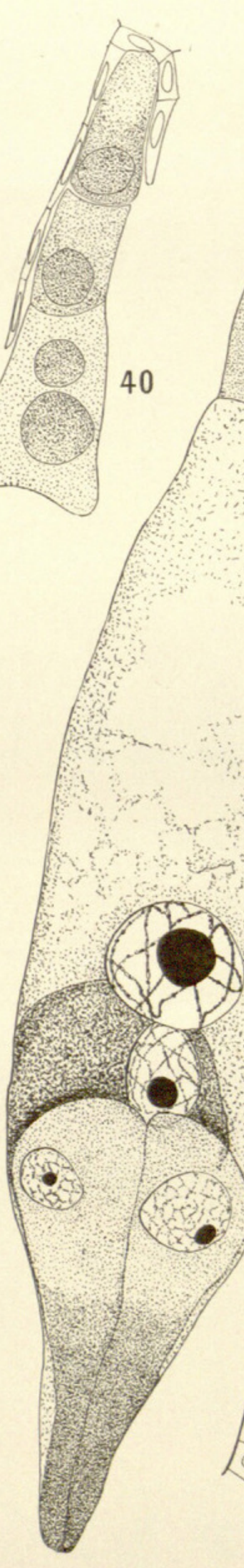

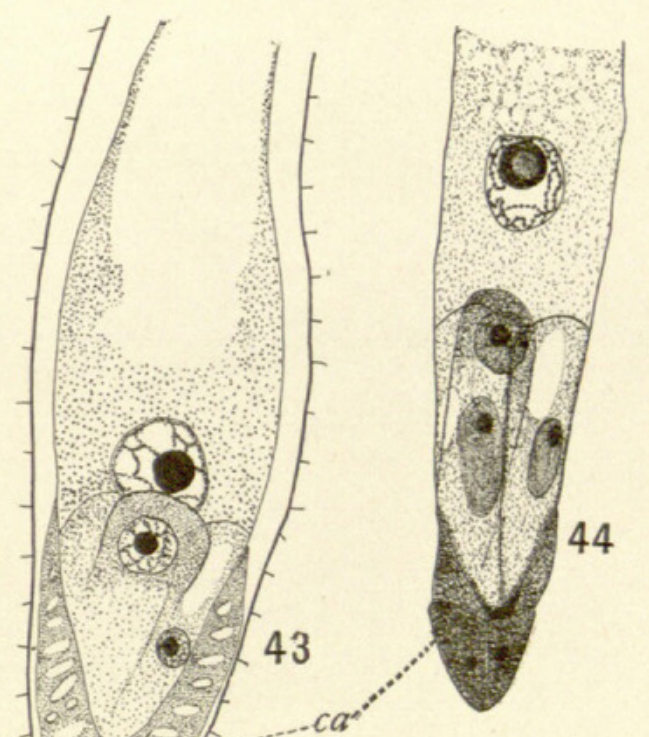

45
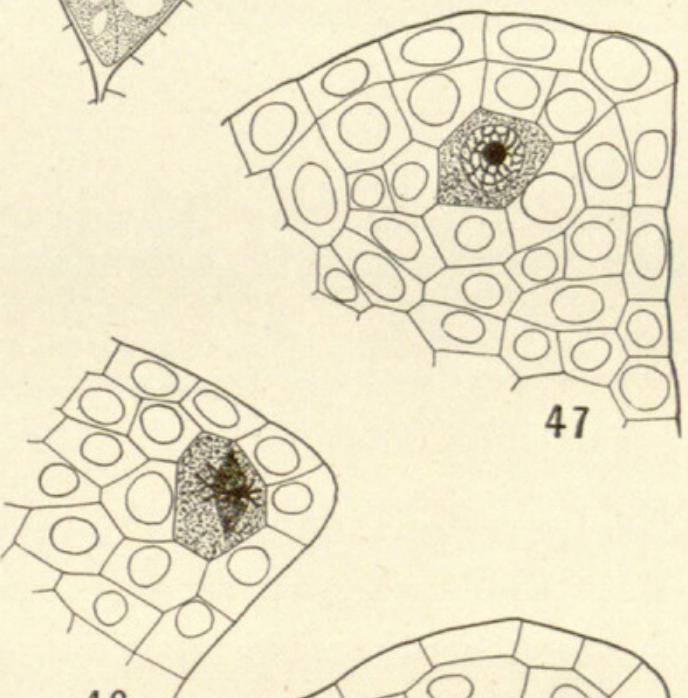

46

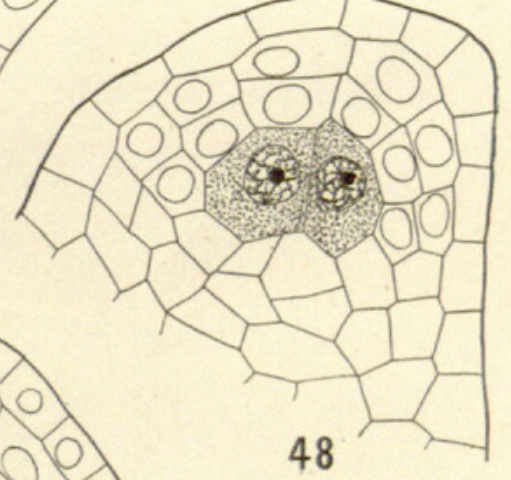

48

MERRELL on SILPHIUM 

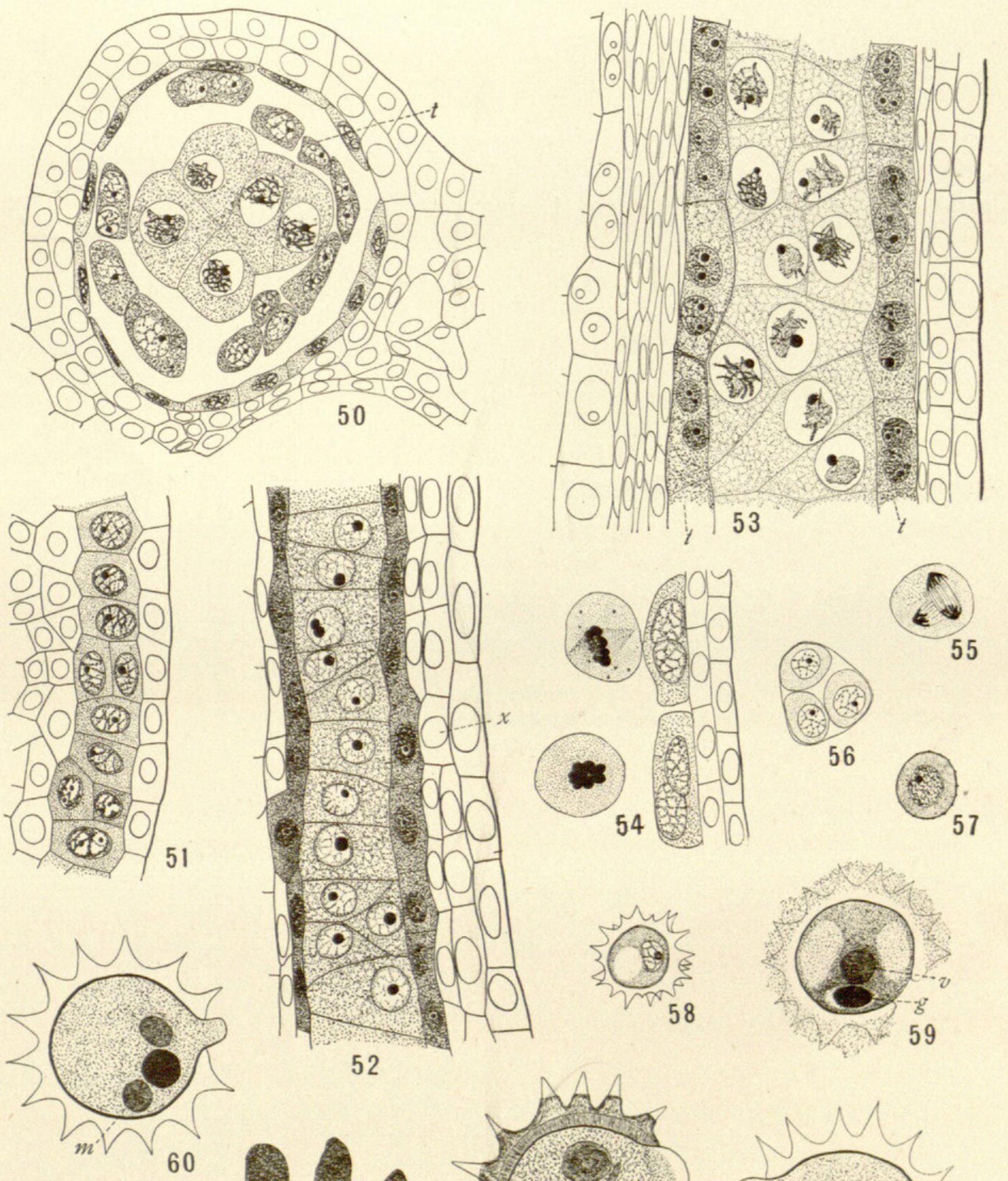

Wtom del
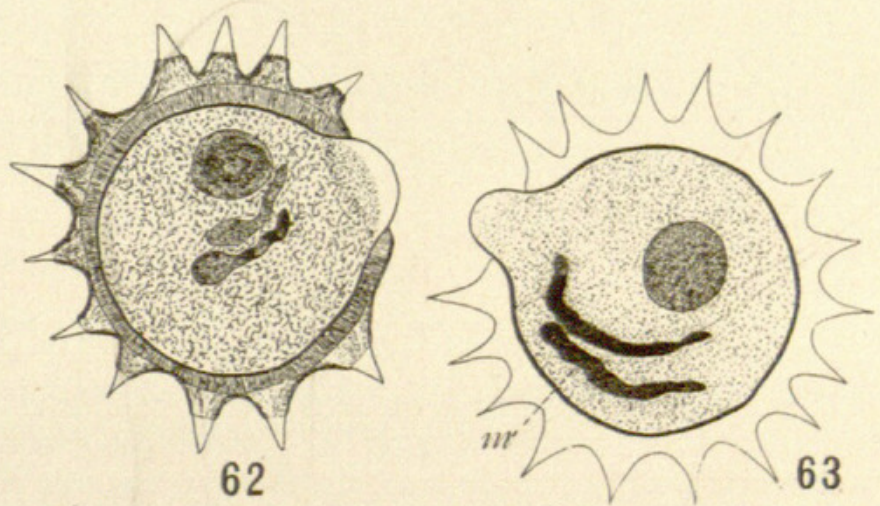

MERRELL on SILPHIUM 


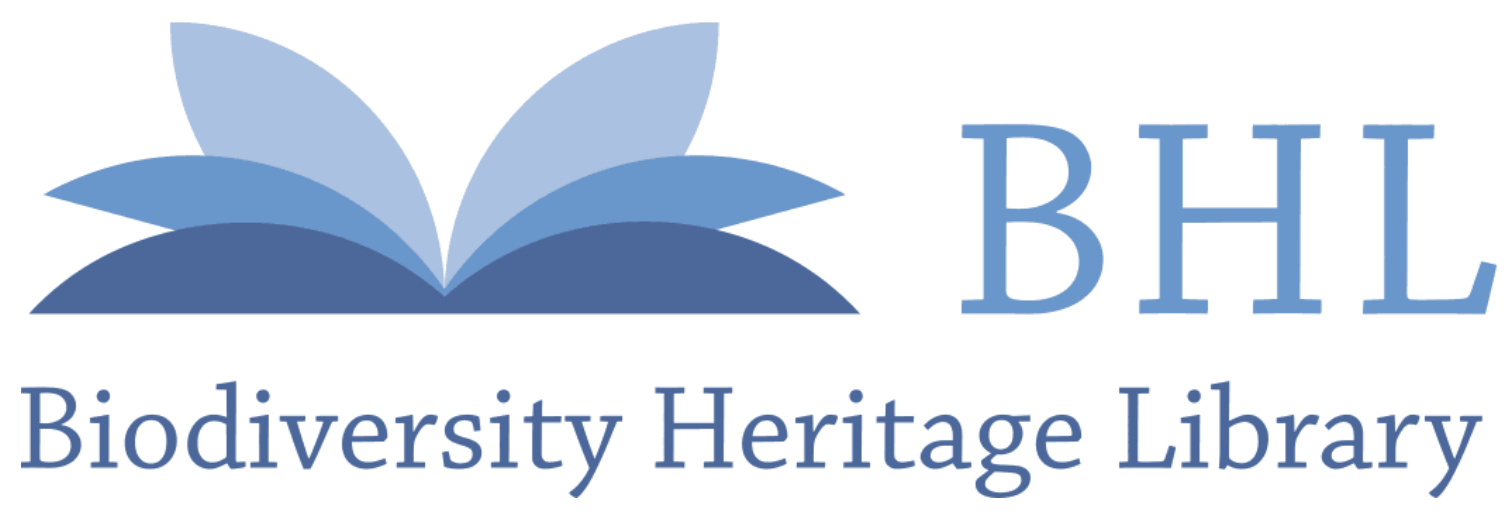

Merrell, William Dayton. 1900. "A Contribution to the Life History of Silphium." Botanical gazette 29(2), 99-133. https://doi.org/10.1086/327953.

View This Item Online: https://www.biodiversitylibrary.org/item/95198

DOI: https://doi.org/10.1086/327953

Permalink: $\underline{\text { https://www.biodiversitylibrary.org/partpdf/223038 }}$

\section{Holding Institution}

Missouri Botanical Garden, Peter H. Raven Library

\section{Sponsored by}

Missouri Botanical Garden

\section{Copyright \& Reuse}

Copyright Status: Public domain. The BHL considers that this work is no longer under copyright protection.

This document was created from content at the Biodiversity Heritage Library, the world's largest open access digital library for biodiversity literature and archives. Visit BHL at https://www.biodiversitylibrary.org. 